\title{
PERLINDUNGAN KONSUMEN DALAM KONTRAK TRANSAKSI \\ E-COMMERCE BERDASARKAN HUKUM PERDAGANGAN \\ INTERNASIONAL
}

Oleh :

Rahmadi Indra Tektona, SH, MH $^{\infty}$

\begin{abstract}
ABSTRAK
Dalam perkembangan ekonomi pada saat sekarang ini sudah mulai meninggalkan cara-cara yang konvensional kita mulai menginjak pada transaksi elektronik dan mulai sering digunakan pada saat sekarang ini, kadangkala terjadi pelanggran dalam kontrak perjanjian antar pihak dalam transaksi tersebut, perlindungan hukum terhadap para pihak masihlah kurang, oleh karena itu perlu kiranya ada perlindungan hukum yang jelas.
\end{abstract}

Kata kunci : Penyelesaian Sengketa, transaksi E-Commerce, Hukum Perdagangan Internasional.

\section{PENDAHULUAN}

Pada saat sekarang ini perkembangan Teknologi Informasi, telah mengakibatkan beragamnya aneka jenis jasa-jasa (features) fasilitas telekomunikasi yang ada, serta semakin canggihnya produk-produk teknologi informasi yang mampu mengintegrasikan semua media informasi. Tetapi ironisnya, dinamika masyarakat Indonesia yang masih baru tumbuh dan berkembang menuju masyarakat industri dan masyarakat Informasi, seolah masih tampak asing untuk mengiringi perkembangan teknologi yang ada. Dengan kemampuan jaringan teknologi informasi dan akses yang semakin berkembang dengan sangat pesat dan pada akhirnya transaksi perniagaan pun dilakukan di dalam jaringan komunikasi tersebut. Jaringan publik mempunyai keunggulan dengan adanya efisiensi biaya dan waktu. Sesuai dengan sifat jaringan publik yang mudah untuk diakses oleh setiap orang menjadikan hal ini sebagai kelemahan bagi jaringan itu.

\footnotetext{
${ }^{\infty}$ Dosen Fakultas Hukum Universitas Jember.
} 
Peran Electronic Commercne dalam perdagangan internasional pada saat sekarang ini cukup pesat perkembangannya, hal tersebut dikarenakan sangat efisisen dan efektif sehingga perhitungan operational cost dapat ditekan. Selain itu berkat dukungan teknologi juga secara teknis dapat dilakukan dengan sangat mudah dan praktis. Sistem jaringan yang terpadu dan bergerak dalam sistem on line networking management mempercepat arus transaksi dan sirkulasi asset bagi intra pelaku bisnis dalam skala global yang lintas batas teritorial (Jurisdiction). Akan tetapi juga sering terjadi penipuan yang dilakukan oleh orang-orang yang tidak bertanggung jawab seperti menggunakan kartu kredit curian (carding), mereka menggunakan kartu kredit milik orang lain untuk melakukan transaksi, hal ini mengakibatkan kerugian kepada banyak pihak, seperti pihak perusahaan pemilik barang dagangan, bank yang mengeluarkan kartu kredit tersebut, dan yang paling utama adalah nama bangsa Indonesia yang menjadi buruk karena dituding sebagai sarang pencuri dunia maya. Bila kita melihat pada pasal 1320 BW dan 1338 (1) BW tentang syarat sahnya perjanjian dan asas konsensualitas bisa ditarik secara substansial untuk mampu mengakomodir dan mengadopsi substansi yang ada dalam pola pelaku electronic commerce tersebut menjadi berkekuatan legal. Tetapi juga jika dilihat dari cara pandang yuridis ada beberapa hal essensial menyangkut hak dan kewajiban para pihak yang saling terkait tersebut.

Indonesia pada Tahun 2008 lalu telah mengeluarkan UU mengenai Informasi dan Transaksi Elektronik, yakni, UU No.11 Tahun 2008 Tentang Informasi dan Transaksi Ekonomi, yang pada dasarnya sudah memberikan perlindungan yang cukup terhadap transaksi ekonomi melalui internet yang dilakukan dalam yuridiksi Republik Indonesia, tetapi jangan lupa, dalam dunia internet tidak hanya sebatas negara Indonesia, melainkan sudah tidak ada batas-batas yang jelas lagi bagi suatu negara.

Bila kita melakukan transaksi melalui perjanjian dalam dunia maya hanya berdasar akan kepercayaan saja, kadangkala juga bisa terjadi wanprestasi dalam e commerce, dan hal tersebut sangatlah sulit dibuktikan di muka persidangan dan bila tejadi antar negara maka dasar hukum mana yang akan digunakan di dalam menyelesaikan sengketa itu hal itu masih menjadi pertanyaan besar pada saat sekarang ini, memang kita lebih diuntungkan dengan adanya e commerce karena biaya murah dan lebih menghemat waktu tetapi di balik semua itu ternyata ada permasalahan yang harus kita cari solusinya. 
Ketidakjelasan hubungan hukum antar pelaku e-commerce, yang tentu salah satunya bertindak sebagai konsumen, bermuara pada kondisi tidak terlindunginya konsumen. Sudah sepatutnya apabila konsumen, terutama konsumen terakhir sebagai sasaran terbesar dalam transaksi e-commerce, mendapat perlindungan dari berbagai perilaku usaha produsen yang merugikan. Ada beberapa permasalahan terhadap konsumen yang dapat disoroti akibat tidak jelasnya hubungan hukum dalam transaksi e-commerce. Pertama, mengenai penggunaan klausul baku. Sebagaimana kita ketahui, dalam kebanyakan transaksi di cyberspace ini, konsumen tidak memiliki pilihan lain selain tinggal meng-click icon yang menandakan persetujuannya atas apa yang dikemukakan produsen di website-nya, tanpa adanya posisi yang cukup fair bagi konsumen untuk menentukan isi klausul. Kedua, bagaimana penyelesaian sengketa yang timbul. Para pihak dapat saja berada pada yurisdiksi peradilan di negara yang berbeda. Sementara perdebatan mengenai yurisdiksi diambil ketika melakukan penyelesaian sengketa dalam e-commerce ini tampaknya masih akan cukup panjang, selama masa penentuan saat terjadi dan di mana terjadinya perjanjian e-commerce masih belum menemukan titik temu. Selain itu, diperlukan pula adanya suatu sistem dan mekanisme penyelesaian sengketa khusus untuk transaksi-transaksi e-commerce yang efektif dan murah. Hal ini berkaitan juga dengan privasi dari kalangan konsumen. Seorang praktisi TI Arianto Mukti Wibowo pernah mengemukakan, penggunaan cookies pada beberapa browser seperti internet explorer dari Microsoft telah memungkinkan sistem pada website mengenali pelanggan, dan bahkan pola belanja yang dilakukan si pelanggan tanpa disadari oleh si pelanggan. Contohnya saja untuk konsumen yang telah melakukan beberapa kali pembelian buku di amazon.com, situs tersebut akan berusaha membuat pola untuk mengenali jenis/topik buku-buku kesukaan customer-nya dengan cara meletakkan cookies ke dalam hard-drive si customer. Pada saat si customer itu membuka situs amazon, sistem amazon akan menawarkan jenis/topik yang diperkirakan menjadi kesukaan customer. Mungkin bagi beberapa kalangan, praktek sebagaimana disebutkan di atas dianggap membantu pihaknya dalam melakukan pencarian buku sesuai dengan topik yang disukainya. Namun sebenarnya, di sinilah letak adanya privacy intrusion tersebut. Kebiasaan dan hobi seseorang, bahkan hal-hal yang sangat pribadi, mungkin saja tereksploitasi. 


\section{PERMASALAHAN}

Setelah membaca latar belakang maka kami penulis mencoba untuk mengangkat satu permasalahan yaitu : Bagaimana Perlindungan Konsumen Dalam Kontrak Transaksi E commerce Berdasarkan Hukum Perdagangan Internasional?

\section{PEMBAHASAN}

\section{Kontrak}

Kontrak pada dasarnya merupakan undang-undang yang mengikat dan memiliki konsekuensi hukum bagi para pihak. Oleh karenanya pembahasan berikutnya lebih tepat dengan istilah hukum kontrak (Michael D. Bayles, 1987 dan Lawrence M. Friedman, 2001). Dalam bahasa Inggris, hukum kontrak merupakan terjemahan dari contract of law, sedangkan dalam bahasa Belanda adalah overeenscomstrecht. Friedman (2001) mengartikan hukum kontrak sebagai : “Perangkat hukum yang mengatur aspek tertentu dari pasar dan mengatur jenis perjanjian tertentu"

Beberapa definisi hukum kontrak yang lain, umumnya tidak membahas tahapan kontrak tersebut dibuat dan dilaksanakan. Ensiklopedi Indonesia (dalam Salim, H.S., 2003) mengkajinya dari aspek lingkup pengaturannya, yaitu persetujuan dan ikatan warga hukum, sebagaimana yang tertuang dalam Pasal 1348 KUH Perdata. Tampaknya definisi ini menyamakan pengertian antara kontrak (perjanjian) dengan persetujuan, padahal keduanya berbeda. Kontrak (perjanjian) merupakan salah satu sumber perikatan, sedangkan persetujuan merupakan salah satu syarat sahnya kontrak, sebagaimana yang diatur dalam Pasal 1320 Kitab Undang-undang Hukum Perdata (KUH Perdata).

Adalah lebih tepat apabila kita mendasarkan pada pendapat Van Dunne (1990), seorang ahli hukum perdata Belanda, yang tidak hanya mengkaji dari sisi kontraktual belaka, akan tetapi juga memperhatikan tahapan-tahapan sebelumnya. Yang dimaksud dengan tahapan-tahapan sebelumnya adalah tahap precontractual yang merupakan tahap penawaran dan penerimaan dan postcontractual yang merupakan pelaksanaan perjanjian. Hubungan hukum adalah hubungan yang menimbulkan akibat hukum. Akibat hukum, yaitu timbulnya hak dan kewajiban. Hak berupa kenikmatan, sedangkan kewajiban berupa beban. 
Dari pendapat dan definisi hukum kontrak di atas, maka definisi hukum kontrak adalah sebagai berikut :

"Keseluruhan dari kaidah-kaidah hukum yang mengatur hubungan hukum antara dua pihak atau lebih berdasarkan kata sepakat untuk menimbulkan akibat hukum “

Dengan demikian, maka unsur-unsur yang tercantum dalam hukum kontrak adalah sebagai berikut :

\section{Adanya Kaidah Hukum}

Kaidah dalam hukum kontrak dibagi menjadi 2 (dua) bagian : tertulis dan tidak tertulis. Kontrak hukum kontrak tertulis adalah kontrak kaidah-kaidah hukum yang terdapat di dalam peraturan perundang-undangan, traktat, dan yurisprudensi. Sedangkan kaidah hukum kontrak tidak tertulis adalah kaidah- kaidah hukum yang timbul, tumbuh, dan hidup dalam mesyarakat (konsep yang berasal dari hukum adat).

2. Adanya Subjek Hukum

Subjek hukum dalam istilah lain adalah rechtsperson, yang diartikan sebagai pendukung hak dan kewajiban. Yang menjadi subjek hukum dalam hukum kontrak adalah kreditur dan debitur. Kreditur adalah orang yang berpiutang, sedangkan debitur adalah orang yang berutang.

3. Adanya Prestasi ( Objek Hukum )

Prestasi merupakan hak kreditur dan menjadi kewajiban bagi debitur. Prestasi menurut Pasal 1234 KUH Perdata terdiri dari 4 (empat) hal :
a. memberikan sesuatu
b. berbuat sesuatu, dan
c. tidak berbuat sesuatu

4. Kata Sepakat

Di dalam Pasal 1320 KUH Perdata ditentukan 4 (empat) syarat sahnya suatu perjanjian. Salah satunya adalah kata sepakat (konsensus). Kesepakatan adalah persesuaian pernyataan kehendak antara para pihak.

5. Akibat Hukum

Setiap perjanjian yang dibuat oleh para pihak, akan menimbulkan akibat hukum. Akibat hukum adalah timbulnya hak dan kewajiban. Hak adalah suatu kenikmatan dan kewajiban adalah suatu beban. 


\section{Kebebasan Berkontrak}

Asas Kebebasan Berkontrak (Contractvrijheid Beginselen)

Banyak pendapat ahli-ahli hukum tentang asas-asas dalam suatu perjanjian, namun pada dasarnya bertujuan untuk tercapainya kepastian hukum, ketertiban hukum, dan keadilan berdasarkan asas konsensualisme (berhubungan dengan lahirnya suatu perjanjian).

Terdapat 5 (lima) asas penting dalam suatu perjanjian, yaitu :

1. Asas Kebebasan Berkontrak, sebagaimana hasil analisis Pasal 1338 ayat (1) KUH Perdata, yang berbunyi : "Semua perjanjian yang dibuat secara sah berlaku sebagai undang-undang bagi mereka yang membuatnya”. Asas Kebebasan Berkontrak ini memberikan kebebasan kepada para pihak untuk :

a. membuat atau tidak membuat perjanjian

b. mengadakan perjanjian dengan siapapun

c. menentukan isi perjanjian dengan siapapun

d. menentukan bentuknya perjanjian, yaitu tertulis atau lisan.

2. Asas Konsensualisme, sebagaimana dalam Pasal 1320 ayat (1) KUH Perdata. Dalam pasal ini ditentukan bahwa salah satu syarat sahnya perjanjian, yaitu adanya kesepakatan kedua belah pihak. Asas konsensualisme pada umumnya tidak diadakan secara formal, tetapi cukup dengan adanya kesepakatan kedua belah pihak. Disini kesepakatan merupakan persesuaian antara kehendak dan pernyataan yang dibuat oleh kedua belah pihak.

3. Asas Pacta Sunt Servanda, merupakan asas kepastian hukum sebagai akibat perjanjian. Asas ini dapat disimpulkan dari Pasal 1338 ayat (1) KUH Perdata yang berbunyi : "Perjanjian yang dibuat secara sah berlaku sebagai undang- undang" Selain itu pada asas ini juga dikatakan bahwa pihak lain (hakim atau pihak ketiga) harus menghormati dan tidak boleh mengintervensi substansi kontrak yang dibuat para pihak, sebagaimana layaknya sebuah undang-undang.

4. Asas Itikat Baik (Goede Trouw) Asas ini dapat disimpulkan dalam Pasal 1338 ayat (3) KUH Perdata yang berbunyi : "Perjanjian harus dilaksanakan dengan itikat baik". Asas itikat baik ini merupakan asas para pihak, yaitu pihak kreditur dan debitur harus melaksanakan substansi kontrak berdasarkan kepercayaan atau keyakinan yang teguh atau kemauan yang baik dari para pihak. Asas itikat baik ini dibagi 2 (dua) : itikat baik nisbi, dimana orang memperhatikan tingkah 
laku nyata orang atau subjek. Sedangkan itikat baik mutlak, penilaiannnya terletak pada akal sehat dan keadilan, dan penilaian keadaan yang dibuat dengan ukuran objektif (penilaian yang tidak memihak) menurut norma-norma yang objektif.

5. Asas Kepribadian (Personalitas) Asas ini merupakan asas yang menentukan bahwa seseorang akan melakukan dan atau membuat kontrak hanya untuk kepentingan perseorangan saja, sebagaimana dalam Pasal 1315 KUH Perdata yang berbunyi : "Pada umumnya seseorang tidak dapat mengadakan perikatan atau perjanjian selain untuk dirinya sendiri”, dan Pasal 1340 KUH Perdata yang menyatakan bahwa : "Perjanjian hanya berlaku antara pihak yang membuatnya". Namun ketentuan ini ada pengecualiannya sebagaimana yang diintrodusir dalam Pasal 1317 KUH Perdata, yang menyatakan : "Dapat pula perjanjian diadakan untuk kepentingan pihak ketiga, bila suatu perjanjian yang dibuat untuk diri sendiri, atau suatu pemberian kepada orang lain, mengandung suatu syarat semacam itu”. Pasal ini mengkonstruksikan bahwa seseorang dapat mengadakan perjanjian untuk kepentingan pihak ketiga.

Sedangkan dalam Pasal 1318 KUH Perdata, tidak hanya mengatur perjanjian untuk diri sendiri, tetapi juga untuk kepentingan ahli warisnya dan untuk orang-orang yang memperoleh hak dari padanya. Jika dibandingkan dengan kedua pasal tersebut, maka dalam Pasal 1317 KUH Perdata mengatur perjanjian untuk pihak ketiga, sedangkan dalam Pasal 1318 KUH Perdata untuk kepentingan :

(a) diri sendiri,

(b) ahli warisnya, dan

(c) orang-orang yang memperoleh hak

Kebebasan berkontrak merupakan suatu "kebebasan individu", para pihak diberikan kebebasan untuk mengatur sendiri berdasarkan kepentingan- kepentingannya dimana peran Pengadilan hanya sebagai melaksanakan. Kebebasan berkontak yang berkeadilan sangat didukung demi tercapainya tujuan yang menekankan keperluan akan stabilitas, kepastian dan konsistensi.

Ada 3 aspek nilai untuk menentukan bilamana suatu kontrak adalah tidak adil.

1. Adanya ketidakseimbangan dalam "Kekuatan Dalam Tawar Menawar".

Kontrak yang dipengaruhi oleh ketidakseimbangan dalam kekuatan tawar menawar adalah menyerahkan keuntungan yang berlebihan kepada salah satu pihak. 
Ketidakseimbangan dari posisi tawar menawar juga dapat terjadi dimana ketidakadilan manfaat (keuntungan) dilakukan dari pihak - pihak yang tidak memiliki pendidikan yang tinggi atau yang mempunyai pemikikiran yang lemah atau pihak yang secara keuangan tidak mencukupi. Setiap orang seharusnya tidak mengambil manfaat (keuntungan) dari suatu kontrak yang tidak adil yang dibuat dalam keadaan dimana pihak lain didalam keadaan tekanan ekonomi dan sosial.

2. Bentuk Kontrak - Kontrak Standar

Berdasarkan kontrak - kontrak standar maka pihak yang lemah yang memerlukan barang - barang dagangan atau jasa - jasa sering tidak pada posisi untuk dapat mempelajari dengan maksud untuk mendapatkan ketentuan - ketentuan yang lebih baik. Kedaulatan dari pada para pihak terabaikan. Diperlukan peranan dari pada pembuat undang - undang dan pengadilan - pengadilan untuk mengatur beberapa kontrak yang mengorbankan prinsip - prinsip dasar dari kebebasan berkontrak.

\section{Ketertiban Umum}

Ini adalah alasan ke-3 dimana "kontrak yang tidak adil" secara sah dan hukum dipertanyakan. Tidak ada ketentuan yang tepat mengenai pengertian "Ketertiban Umum". Hal - hal, dengan alasan keteriban umum, yang dapat membuat kontrak menjadi tidak berlaku dapat dibagi menjadi 5 (lima) kelompok yaitu : sehubungan dengan obyek yang tidak sah oleh hukum yang umum atau peraturan; obyek yang berbahaya bagi pemerintahan yang baik baik dalam lapangan hubungan dalam atau luar negeri; yang mencampuri proses peradilan yang sudah berjalan dengan baik; membahayakan terhadap perkawinan dan moral; dan secara ekonomis bertentangan dengan kepentingan umum.

\section{E-Commerce}

Electronic Commerce (Perniagaan Elektronik), oleh para ahli dan pelaku bisnis dicoba dirumuskan definisinya dari terminologi E-Commerce (Perniagaan Elektronik). Secara umum e-commerce dapat didefinisikan sebagai segala bentuk transaksi perdagangan/perniagaan barang atau jasa (trade of goods and service) dengan menggunakan media elektronik. Jelas, selain dari yang telah disebutkan di atas, bahwa kegiatan perniagaan tersebut merupakan bagian dari kegiatan bisnis ("e-commerce is a part of e-business".) ${ }^{1}$

\footnotetext{
${ }^{1}$ www.geocities.com/amiwibowo/resourch/hukumpdf.
} 
Legalitas dari suatu kontrak atau perjanjian di Electronic Commerce menjadi sebuah fenomena yuridis yang relatif baru bagi Indonesia. Dalam perspektif hukum, suatu perikatan adalah suatu hubungan hukum antara subyek hukum dimana satu pihak berkewajiban atas suatu prestasi sedangkan pihak yang lain berhak atas prestasi tersebut. Berdasarkan pasal 1233 KUHPerdt., adanya suatu perikatan adalah lahir karena suatu perjanjian atau karena suatu undang-undang. Selanjutnya, dalam pasal 1320 KUHPerdt. dijelaskan bahwa syarat-syarat sah-nya suatu perjanjian adalah meliputi Syarat Subyektif dan Syarat Obyektif. Syarat Subyektif meliputi adanya (1) Kesepakatan, dan (2) Kecakapan (bersikap tindak dalam hukum) untuk membuat suatu perikatan. Sedangkan syarat obyektif, adalah meliputi (3) suatu hal yang tertentu (obyeknya harus jelas), dan (4) merupakan suatu kausa yang halal (tidak bertentangan dengan undangundang, kesusilaan dan ketertiban umum.

Dalam UU No.11 Tahun 2008 Tentang Informasi Dan Transaksi Ekonomi juga dijelaskan dengan mengenai Transaksi Elektronik adalah perbuatan hukum yang dilakukan dengan menggunakan komputer, jaringan komputer dan atau media elektronik lainnya, sehingga untuk yuridiksi di Indonesia, sudah mempunyai dasar hukum yang kuat, tinggal bagaimana nanti penegak hukum yang ada menerapkan di lapangan. Bila kita bicara tentang transaksi e- commerce tentu saja yang menjadi dasarnya adalah kontrak, dalam hukum Inggris bila ada kontrak dengan unsur asing, maka hukum yang dipergunakan dalam menyelesaikan sengketa ialah hukum yang tepat, Menurut pandangan Dicey, "the term proper law of cantract means the law or laws by which the parties intended, or may fairly be presumed to have intended, the contract to be governed" . Ini dikenal sebagai pandangan yang subyektif dan penekannanya entu diberikan pada niat dari para pihak. Terdapat juga pandangan yang lain mengenai transaksi elektronik, yakni pandangan secara obyektif yang didukung oleh Lord Denning. Beliau mengemukakan bahwa "the proper law of the contract depens not so much on the place whre it is made, nor even on the intention of the parties on the places where it is to be performed but on the place with which it has the most sbstansial connection”. Boisssvain v Weil (1949). Dari pandangan di atas mengani unsur subyektif dan obyektif dari suatu kontrak dapat kita ambil kesimpulan,

\footnotetext{
${ }^{2}$ Arthur Lewis, Dasar-dasar hukum bisnis, Introduction to Business Law, 2009 Cetakan I, Nusamedia.
} Hal 488 
bahwa penyelesaian dari kontrak perjanjian antar kedua belah pihak dalam mencari tempat penyelesaian tergantung dari kesepakatan awal dari masing-masing pihak

Dalam Konvensi Roma Pasal 3 dengan jelas menetapkan bahwa para pihak bebas memilih hukum yang hendak diberlakukan pada kontrak mereka, dengan pengecualian bilasemua unsur lain yang berhubungan dengan situasi itu hanya terkait dengan satu negara saja. Bila demikian halnya yang berlaku adalah peraturan-peraturan di negara itu, hal tersebut disebut dengan "mandatory rules", Dalam pasal 4 juga tercantum apabila para pihak tidak memilih hukum tertentu untuk mengatur kontrak, maka kontrak akan diatur dengan hukum negara yang paling terkait

\section{Aspek Kontrak Perdagangan Internasional}

\section{Kontrak Perdagangan Internasional (secara umum) berdasarkan UNCSIG}

Kontrak perdagangan internasional secara umum diatur dalam United Nations in Contracts for International Sale of Goods (UNCISG) 1980 dan 1986. Indonesia belum meratifikasi untuk UNCISG tahun 1980, meskipun demikian konvensi ini patut kita pertimbangkan sebagai platform bagi konvensi jual beli internasional yang baru. Konvensi ini mengatur masalah-masalah kontraktual yang berhubungan dengan kontrak jual beli internasional. Konvensi ini sebenarnya hanya mengatur masalah jual beli antara business to business (B2B), sedangkan e-commerce yang kita bahas disini adalah hubungan bisnis antara Business to Consumer (B2C). Didalam konvensi tersebut terdapat beberapa prinsip yang dapat di adopsi dalam makalah ini. antara lain adalah ${ }^{3}$ :

1. Bahwa kontrak tidak harus dalam bentuk tertulis (in writing from), tetapi kontrak tersebut bisa saja berbentuk lain. Berdasarkan aturan tersebut suatu kontrak dapat juga dalam bentuk data tapi didalam UNCISG ini belum diatur secara spesifik mengenai e-commerce. Berdasarkan hal tersebut diatas maka suatu kontrak jual-beli secara internasional yang menggunakan e-commerce berdasarkan hukum internasional secara hukum mengikat (legally binding) atau mempunyai kekuatan hukum.

2. CISG mencakup materi pembentukan kontrak secara internasional yang bertujuan meniadakan keperluan menunjukkan hukum negara tertentu dalam kontrak perdagangan internasional serta untuk memudahkan para pihak dalam hal terjadi konflik antar sistem hukum. CISG berlaku terhadap kontrak untuk

\footnotetext{
$3 / /$ www.geocities.com/amwibowo/resource/.htm
} 
FH UIB - Jurnal Supremasi, Vol. VI, No.2, September 2016 -

pejualan barang yang dibuat diantara pihak yang tempat dagangnya berada di negara yang berlainan pasal (1(1)). Dengan demikian yang menentukan adalah tempat perdagangannya dan bukan kewaarganegaranya. Dalam konteks ecommerce tempat kedudukan dari Merchant yang adalah kedudukan hukum yang tercantum di digital certificate miliknya. Suatu kontrak yang dibuat berdasarkan CISG atau yang tunduk kepada CISG harus ditafsirkan berdasarkan prinsip-prinsip yang tercantum dalam CISG dan kalau CISG belum menentukan, berdasarkan kaidah-kaidah hukum perdata internasional. Disamping itu, CISG menerima kebiasaan dagang serta kebiasaan antara para pihak sebagai dasar penafsiran ketentuan kontrak. Seperti halnya dalam hukum kontrak Indonesia, itikad baik dijadikan prinsip utama dalam penaafsiran utama dalam penafsiran ketentuan dan pelaksanaan kontrak.

\section{Kontrak berdasarkan UNCITRAL model law on Electronic Commerce}

Model law ini mengatur tentang e-commerce secara umum, mulai dari definisidefinisi yang dipakai, bentuk dokumen-dokumen yang dipakai dalam e-commerce, keabsahan kontrak, saat terjadinya kontrak selain itu model law ini mengatur juga tentang carriage of goods. Pendekatan yang diambil dalam model law ini adalah bahwa suatu informasi tidak dapat dikatakan tidak mempunyai kekuatan hukum, karena informasi itu berbentuk data message. Berdasarkan pendekatan diatas maka suatu data messaages apapun bentuk atau formatnya dapat dikatakan mempunyai kekuatan. Pendekatan ini akan menimbulkan suatu kepastian dikemudian hari apabila terdapat suatu bentuk/format data messages dalam bentuk yang baru. Pendekatan ini juga akan menyebabkan suatu perjanjian yang dibuat dengan e-cmmerce mempunyai kekuatan hukum.

\section{GUIDEC (General Usage for International Digitally Ensured Commerce) dari ICC}

GUIDEC adalah suatu panduan yang dibuat oleh International Chamber of Commerce bagi penggunaan suatu metode yang akan menjamin (ensured) keberadaan suatu dokumen/data elektronis dalam penggunaannya dalam dunia internasional. Panduan ini menggunakan terminologi ensured untuk membedakannya dengan 
terminologi sign dalam hal panandatanganan (sign in/signature) terhadap suatu dokumen. GUIDEC ini dimaksudkan untuk menunjang perkembangan dari e-commerce dengan memberikan kepastian bagi penerapan adanya tandatangan dalam suatu dokumen elektronis. Panduan ini akan menjelaskan berbagai terminologi/istilah yang ada didalam UNCITRAL model law on e-commerce seperti apakah sebenarnya maksud dari penandatangan suatu data messages secara elektronis (electronically signed Messages). Maksud dari penandatanganan disini adalah bukan dilakukan secara fisik, tetapi membutuhkan suatu perangkat elektronik.

Berdasarkan hal-hal tersebut diatas maka hendaknya setiap bentuk kontrak perdagangan internasional dengan menggunakan e- commerce harus didasarkan pada peraturan yang mengatur secara spesifik mengatur tentang e-commerce. Saat terbentuknya kontrak harus menyangkut kapan terjadinya kesepakatan terutama apabila kesepakatan ini terjadi tanpa kehadiran para peserta/pihak. Transaksi di internet kita analogikan sebagai transaksi yang dilakukan tanpa kehadiran para pelaku di satu tampat (beetwen absent person).

Apabila dikemudian hari timbul suatu sengketa mengenai kontrak tersebut, maka pentinglah untuk diketahui hukum mana (hukum dari negara yang mana) yang akan diberlakukan bagi kontrak tersebut. Suatu kontrak e-commerce yang bagus akan menjelaskan secara eksplisit hukum mana yang berlaku bagi kontrak itu, tetapi kadangkala pilihan hukum ini tidak dicantumkan. Secara umum dalam menetukan hukum mana yang akan berlaku adalah berdasarkan prinsip yuridiksi negara manakah yang memiliki hubungan yang terdekat dan mempunyai hubungan yang erat dengan kontrak tersebut. Tempat dimana terjadinya suatu kontrak adalah suatu hal yang patut dipertimbangkan dalam penentuan hukum mana yang berlaku bagi kontrak tersebut, meskipun hal ini bukanlah suatu faktor yang penting. Suatu kontrak yang dibuat dengan menggunakan sarana telekomunikasi yang yang bersifat instan/seketika dapat dianggap berada dibawah yurisdiksi dari tempat dimana offeror menerima acceptance. Sedangkan bila diterapkan prinsip postal acceptance, maka tempat terjadinya acceptance adalah tempat dimana acceptance tersebut dikirimkan yang akan menetukan hukum mana yang berlaku bagi kontrak tersebut. Untuk mencegah ketidakpastian hukum mana yang akan berlaku bagi suatu kontrak maka dalam membuat suatu kontrak baik itu berupa offer atau acceptance para pihak hendaknya menjelaskan dimana, kapan dianggap kontrak itu terjadi dan hukum mana yang akan berlaku bagi kontrak tersebut. 


\section{Penegakan hukum (enforcement) bagi transaksi internasional}

Masalah penegakan hukum (enforcement) bagi penyelesaian suatu sengketa adalah suatu hal yang sangat penting diperhatikan dalam suatu sengketa yang mempunyai aspek internasional. Terdapat kemungkinan suatu putusan dari suatu pengadilan di suatu negara tidak dapat ditegakkan/diberlakukan (enforce) di negara yang lain. Hal ini disebabkan adanya masalah kedaulatan suatu negara dimana suatu putusan pengadilan asing pada prinsipnya tidak dapat di eksekusi apabila eksekusi berada di luar yurisdiksi negara tersebut. Permasalahan tersebut diatas dapat diantisipasi dengan memilih lembaga arbitrase sebagai pilihan forum penyelesaian sengketa bagi suatu kontrak internasional. Pilihan arbitrase sebagai forum penyelesaian sengketa akan membawa kepastian hukum bagi para pihak apabila terjadi sengketa. Karena terhadap putusan arbitrase ini dapat dilakukan enforcement dinegara yang lain, sehingga akan membawa ketenangan bagi para pihak. Terhadap putusan arbiter yang berada diluar yurisdiksi suatu negara/ arbitrase asing dapat dilakukan enforcement pasal

2 konvensi United Nations Convention on the Recogniton and enforcement Arbiral Award (the New York Convention).

\section{KESIMPULAN}

Berdasarkan dari apa yang telah dikemukakan, dapat kita simpulkan yaitu :

1. Kegiatan-kegiatan dalam e-commerce secara general masih dapat dikategorikan sebagai tindakan perdagangan/peniagaan biasa, walaupun terdapatnya hal-hal yang signifikan yang membedakannya seperti media elektronik yang menggantikan paper-based transaction. Dapat dikatakan beberapa peraturan hukum yang telah ada sekarang ini sudah dapat mencukupi, baik dengan cara melakukan penafsiran secara analogis terhadap tindakan yang ada dalam ecommerce (terhadap aturan yang belum ada) maupun melakukan penafsiran ekstentif dengan cara memberlakukan peraturan hukum pada hal-hal yang secara esensi adalah sama (contohnya: listrik dan data elektronik).

\section{C.2. SARAN}

1. Perlu diperhatikan lebih lanjut bahwa perangkat hukum di Indonesia khususnya hukum perdata pada dasarnya telah mampu menjangkau permasalahanpermasalahan yang timbul. Hukum perdata ini secara umum. (sec.general: norma sdh mampu, tetapi kita msaih butuh pengraturan yang lebih spesifik 
untuk menjamin kepastian hukum bagi setiap perbuatan hukum perdata khususnya di bidang ecom. Untuk sementara, menghadapi kekosongan hukum di Indonesia, diperlukan peran hakim dan para aparat penegak hukum termasuk penasehat hukum, dan kepolisian serta kejaksaan.

2. Perlu dibentuk suatu tim khusus di bidang hukum/regulasi e-commerce sesegera mungkin. Tim khusus ini perlu segera dibentuk untuk mempersiapkan dasar pelaksanaan dari peraturan hukum yang sudah ada pada bidang e- commerce. Kedudukan tim ini di bawah beberapa departemen, seperti Sekretariat Negara, Departemen Perdagangan dan Industri, Departemen Kehakiman, Departemen bidang Telekomunikasi, dan beberapa Departemen lainnya yang berkaitan erat dengan masalah ini. Tim khusus ini dapat bekerja secara inter departemen sehingga segala permasalahan dapat dicakup secara luas.

3. Perlu adanya perlindungan hukum bagi masyarakat pengguna internet yang ingin melakukan transaksi, perlindungan hukum ini hendaknya dilakukan oleh pemerintah, dan pemerintah bertanggung jawab penuh terhadap hal tersebut, karena mau tidak mau penggunaan internet pada saat ini bisa dikatakan merupakan perkembangan zaman yang tidak dapat kita tolak lagi

\section{DAFTAR PUSTAKA}

Arrianto Mukti Wibowo, Tanda tangan digital \& sertifikat digital: Apa itu? 1998 Artikel ini muncul pada Infokomputer edisi Internet Juni 1998

Arthur Lewis, Dasar-dasar hukum bisnis, Introduction to Business Law, 2009 Cetakan I, Nusamedia.

Mertokusumo, Sudikno, Hukum Acara Perdata Indonesia, edisi ke empat, PT Liberty Yogyakarta 1993

Undang-Undang Nomor 8 Tahun 1997 tentang Peraturan dan perundang- undangan, Jurnal Hukum Bisnis, Yasasan Pengembangan Hukum Bisnis, Vol 1 tahun 1997

Undang-Undang No 11 Tahun 2008 Tentang Informasi dan Transaksi Elektronik 